\title{
Use of multiple laboratory tests including anti-factor Xa to optimally manage anticoagulation during ECMO
}

\author{
Patrick M. Honore*, Leonel Barreto Gutierrez, Luc Kugener, Sebastien Redant, Rachid Attou, Andrea Gallerani and \\ David De Bels
}

We read with great interest the recent article by Chlebowski et al., who recommend the use of multiple laboratory tests including anti-factor Xa (anti-Xa) to optimally manage anticoagulation during ECMO [1]. Anti$\mathrm{Xa}$ directly measures heparin inhibition of factor Xa and is increasingly used to measure heparin effect, especially in pediatric patients [1]. Anti-Xa assay correlates better with unfractionated heparin (UFH) concentration than with activated clotting time (ACT) or activated partial thromboplastin time (aPTT) [2,3]. The major criticism made of using anti-Xa in isolation to titrate heparin for anticoagulation is that while it is a direct measure of heparin effect, it does not represent the overall hemostatic state of the patient [1]. For example, a patient who before heparin therapy is highly prothrombotic may still be prothrombotic with what is considered to be a therapeutic effect of heparin based on anti-Xa levels [1]. We would like to make some comments. Prior to the COVID-19 pandemic, we routinely used anticoagulation for veno-arterial ECMO (VA-ECMO), but not for veno-venous ECMO (VV-ECMO) [4]. We have found the situation to be totally different in COVID-19 patients treated with VV-ECMO. We have needed to use very high doses of heparin, from 20,000 IU up to 50, $000 \mathrm{IU}$, and despite those high doses, we have had several cases of thrombosis. In an attempt to avoid both bleeding and thrombosis, we have started monitoring anticoagulation in these patients with both anti-Xa and aPTT. If the anti-Xa level is within the reference range $(0.3-0.7 \mathrm{IU} / \mathrm{ml})$ but the aPTT is low, we increase the UFH, aiming for an aPTT between 50 and $70 \mathrm{~s}$ (according to a sliding scale). On the other hand, if the aPTT is between 50 and $70 \mathrm{~s}$, but the anti-Xa is greater than 1 $\mathrm{IU} / \mathrm{ml}$, we reduce the UFH (again according to a sliding scale). By adjusting the UFH dose on the basis of a combination of two different measurements, we have aimed to improve our anticoagulation strategy and potentially reduce bleeding and thrombosis. Obviously, to confirm this, we would need to perform a randomized controlled trial. A sliding scale for UFH is easy to obtain whereas it is somewhat more difficult for anti-Xa. With this in mind, we have included our sliding scale for anti-Xa at the end of this letter (adapted from a sliding scale from the literature (Table 1) [5]). 
Table 1 Adjustment of unfractionated heparin dose during ECMO according to anti-Xa activity and body weight. 20,000 IU UFH + 44 cc NaCl 0.9\%

\begin{tabular}{llllllllll}
\hline Anti-Xa activity & Bolus & Variation & $55-64 \mathrm{~kg}$ & $65-74 \mathrm{~kg}$ & $75-84 \mathrm{~kg}$ & $85-94 \mathrm{~kg}$ & $95-104 \mathrm{~kg}$ & $105-114 \mathrm{~kg}$ & $115-124 \mathrm{~kg}$ \\
\hline$<0.2$ & $26 \mathrm{U} / \mathrm{kg}$ & $\uparrow 96 \mathrm{U} / \mathrm{kg} / \mathrm{h}$ & $\uparrow 0.6 \mathrm{cc} / \mathrm{h}$ & $\uparrow 0.7 \mathrm{cc} / \mathrm{h}$ & $\uparrow 0.8 \mathrm{cc} / \mathrm{h}$ & $\uparrow 0.9 \mathrm{cc} / \mathrm{h}$ & $\uparrow 1 \mathrm{cc} / \mathrm{h}$ & $\uparrow 1.1 \mathrm{cc} / \mathrm{h}$ & $\uparrow 1.2 \mathrm{cc} / \mathrm{h}$ \\
$0.20-0.29$ & No & $\uparrow 48 \mathrm{U} / \mathrm{kg} / \mathrm{h}$ & $\uparrow 0.3 \mathrm{cc} / \mathrm{h}$ & $\uparrow 0.3 \mathrm{cc} / \mathrm{h}$ & $\uparrow 0.4 \mathrm{cc} / \mathrm{h}$ & $\uparrow 0.4 \mathrm{cc} / \mathrm{h}$ & $\uparrow 0.5 \mathrm{cc} / \mathrm{h}$ & $\uparrow 0.6 \mathrm{cc} / \mathrm{h}$ & $\uparrow 0.7 \mathrm{cc} / \mathrm{h}$ \\
$0.30-0.70$ & No & & & & & & & \\
$0.71-0.80$ & No & $\downarrow 24 \mathrm{U} / \mathrm{kg} / \mathrm{h}$ & $\downarrow 0.1 \mathrm{cc} / \mathrm{h}$ & $\downarrow 0.1 \mathrm{cc} / \mathrm{h}$ & $\downarrow 0.2 \mathrm{cc} / \mathrm{h}$ & $\downarrow 0.2 \mathrm{cc} / \mathrm{h}$ & $\downarrow 0.2 \mathrm{cc} / \mathrm{h}$ & $\downarrow 0.3 \mathrm{cc} / \mathrm{h}$ & $\downarrow 0.3 \mathrm{cc} / \mathrm{h}$ \\
$0.81-0.99$ & No & $\downarrow 48 \mathrm{U} / \mathrm{kg} / \mathrm{h}$ & $\downarrow 0.3 \mathrm{cc} / \mathrm{h}$ & $\downarrow 0.3 \mathrm{cc} / \mathrm{h}$ & $\downarrow 0.4 \mathrm{cc} / \mathrm{h}$ & $\downarrow 0.4 \mathrm{cc} / \mathrm{h}$ & $\downarrow 0.5 \mathrm{cc} / \mathrm{h}$ & $\downarrow 0.6 \mathrm{cc} / \mathrm{h}$ & $\downarrow 0.7 \mathrm{cc} / \mathrm{h}$ \\
$>1$ & No & $\downarrow 96 \mathrm{U} / \mathrm{kg} / \mathrm{h}$ & $\downarrow 0.6 \mathrm{cc} / \mathrm{h}$ & $\downarrow 0.7 \mathrm{cc} / \mathrm{h}$ & $\downarrow 0.8 \mathrm{cc} / \mathrm{h}$ & $\downarrow 0.9 \mathrm{cc} / \mathrm{h}$ & $\downarrow 1.0 \mathrm{cc} / \mathrm{h}$ & $\downarrow 1.1 \mathrm{cc} / \mathrm{h}$ & $\downarrow 1.2 \mathrm{cc} / \mathrm{h}$ \\
\hline
\end{tabular}

The table can be adapted: For 30,000 IU of UFH, use a correction factor of 1.5. For 40,000 IU of UFH, use a correction factor of 2. For 50,000 IU of UFH, use a correction factor of 2.5

\section{Authors' response}

Chlebowski MM, Baltagi S, Carlson M, Levy JH, Spinella PC

The authors agree that COVID-19 patients have increased anticoagulation needs and, as a result, multifactorial analysis of hemostasis utilizing thromboelastography (TEG) in these patients may be even more important due to the multidimensional hemostatic abnormalities that occur with COVID-19 infection [6, 7]. The current literature indicates that diffuse endothelial injury with significant inflammatory activation of platelets and reduced fibrinolysis are major contributors to the hypercoagulable state [6-8]. The use of viscoelastic assays can provide critical information regarding thrombosis risk that traditional coagulation parameters including anti-Xa, INR, PTT, and platelet levels may not provide. Recent studies show that results for these tests may be within or close to reference ranges while TEG results are consistent with profound derangements in hemostasis [6-8]. Specifically, the use of TEG strengthens the assessment of a patient's hemostatic profile by adding information regarding clot strength, a measure of platelet function, and fibrinolysis in a whole blood sample versus other parameters, such as PTT, that are plasma-based. As a result of this data, it is important to also consider that the isolated use of anti-Xa inhibitors to anticoagulate patients with COVID-19 may be inadequate and the addition of viscoelastic assays could indicate the need for antiplatelet agents or antifibrinolytics that could be titrated carefully with serial viscoelastic testing to allow for targeted reduction in the hypercoagulable state while simultaneously reducing the risk of bleeding.

\section{Abbreviations}

Anti-Xa: Anti-factor Xa; ECMO: Extracorporeal membrane oxygenation; WECMO: Veno-venous extracorporeal membrane oxygenation; VAECMO: Veno-arterial extracorporeal membrane oxygenation; UFH: Unfractionated heparin; ACT: Activated clotting time; aPTT: Activated partial thromboplastin time
Acknowledgements

We would like to thank Dr. Melissa Jackson for the critical review of the manuscript.

\section{Authors' contributions}

$\mathrm{PMH}, \mathrm{SR}$, and DDB designed the paper. All authors participated in drafting and reviewing. All authors read and approved the final version of the manuscript.

\section{Funding}

None.

Availability of data and materials

Not applicable.

Ethics approval and consent to participate

Not applicable.

Consent for publication

Not applicable.

\section{Competing interests}

The authors declare to have no competing interests.

Received: 8 June 2020 Accepted: 2 July 2020

Published online: 13 July 2020

\section{References}

1. Chlebowski MM, Baltagi S, Carlson M, Levy JH, Spinella PC. Clinical controversies in anticoagulation monitoring and antithrombin supplementation for ECMO. Crit Care. 2020;24(1):19. https://doi.org/10.1186/ s13054-020-2726-9.

2. Liveris A, Bello RA, Friedmann P, Duffy MA, Manwani D, Killinger JS, Rodriquez D, Weinstein S. Anti-factor Xa assay is a superior correlate of heparin dose than activated partial thromboplastin time or activated clotting time in pediatric extracorporeal membrane oxygenation. Pediatr Crit Care Med. 2014;15(2):e72-9.

3. Delmas C, Jacquemin A, Vardon-Bounes F, Georges B, Guerrero F, Hernandez N, Marcheix B, Seguin T, Minville V, Conil JM, Silva S. Anticoagulation Monitoring Under ECMO Support: A Comparative Study Between the Activated Coagulation Time and the Anti-Xa Activity Assay. J Intensive Care Med. 2020;35(7):679-86. https://doi.org/10.1177/ 0885066618776937. Epub 2018 May 16.

4. Carter KT, Kutcher ME, Shake JG, Panos AL, Cochran RP, Creswell LL, Copeland $\mathrm{H}$. Heparin-sparing anticoagulation strategies are viable options for patients on veno-venous ECMO. J Surg Res. 2019;243:399-409. https://doi.org/10.1016/j.jss.2019.05.050 Epub 2019 Jul 2. 
5. Smith ML, Wheeler KE. Weight-based heparin protocol using antifactor Xa monitoring. Am J Health Syst Pharm. 2010;67(5):371-4. https://doi.org/10. 2146/ajhp090123.

6. Mortus JR, Manek SE, Brubaker LS, Loor M, Cruz MA, Trautner BW, Rosengart TK. Thromboelastographic results and hypercoagulability syndrome in patients with coronavirus disease 2019 who are critically ill. JAMA Netw Open. 2020;3(6):e2011192. https://doi.org/10.1001/jamanetworkopen.2020. 11192.

7. Wright FL, Vogler TO, Moore EE, Moore HB, Wohlauer MV, Urban S, Nydam TL, Moore PK, McIntyre RC Jr. Fibrinolysis shutdown correlates to thromboembolic events in severe COVID-19 infection. J Am Coll Surg. 2020; https://doi.org/10.1016/j.jamcollsurg.2020.05.007.

8. Panigada M, Bottino N, Tagliabue $\mathrm{P}$, et al. Hypercoagulability of COVID-19 patients in intensive care unit. J Thromb Haemost. 2020. https://doi.org/10. 1111/jth.14850 A report of thromboelastography findings and other parameters of hemostasis [published online ahead of print, 2020 Apr 17].

\section{Publisher's Note}

Springer Nature remains neutral with regard to jurisdictional claims in published maps and institutional affiliations. 